\title{
DNA Damage in Gasoline Station Workers Caused by Occupational Exposure to Petrol Vapour in Turkey
}

\author{
Ayfer Beceren $^{1 *}$, Nebahat Akdemir ${ }^{1}$, Gülden Zehra Omurtag², \\ M. Eşref Tatıpınar², Semra Şardaş ${ }^{1}$, \\ 'Marmara University, School of Pharmacy, Department of Pharmaceutical Toxicology, Istanbul, Turkey \\ ${ }^{2}$ Istanbul Medipol University, School of Pharmacy, Department of Pharmaceutical Toxicology, Istanbul, Turkey
}

\begin{abstract}
The refueling of vehicles is a major source of volatile organic compounds generated by used and evaporated fuel. Gasoline workers are directly exposed to various fuel products via many routes in the ambient air. The aim of this study is to determine the potential DNA damage in the peripheral blood samples of the gasoline station workers in Istanbul, Turkey by using the alkaline comet assay. Blood samples were collected from exposed workers $(n=25)$ and healthy controls $(n=14)$ with no history of occupational exposure. Significant difference in the mean total comet scores (TCS) of gasoline station workers $(89.24 \pm 30.83)$ were observed as compared with the control group $(15.64 \pm 16.17)(\mathrm{p}<0.001)$. Results from our study indicate that exposure to petrol vapour induce genotoxic effects, confirming that the gasoline station workers have a high risk of cancer due to their daily occupational exposure.
\end{abstract}

Key words: gasoline station workers, fuel exposure, comet assay, DNA damage

\section{INTRODUCTION}

Gasoline is a mixture of various hydrocarbons; its vapour consists of 95\% aliphatic and alicyclic compounds and aromatic compounds. According to the International Agency of Research on Cancer (IARC), gasoline vapour is included in class of human carcinogens ${ }^{1,2}$. Benzene is a volatile aromatic hydrocarbon solvent used extensively in industry in the past. It continues to be used, in low concentration, in some occupational processes. Benzene is a cytotoxic, hematoxic, immunotoxic and genotoxic aromatic hydrocarbon that is used in many fields in industry. It is also a common environmental contaminant and component of

${ }^{*}$ Corresponding author: Ayfer Beceren

E-mail address: ayfertozan@hotmail.com 
cigarette, gasoline and automobile emissions. It has long been known that benzene causes leukemia, although there are still some ambiguities regarding its mechanism and concentration-response correlation. Chronic exposure to low benzene concentrations in the workplace is associated with blood diseases like aplastic anemia and leukemia ${ }^{3}$. Benzene, toluene and xylene are key aromatic compounds in gasoline. Benzene is listed as a carcinogen for humans and the Association Advancing Occupational and Environmental Health (ACGIH) sets the recommended threshold value of occupational exposure to benzene at $0.5 \mathrm{ppm}$. Exposure to toluene and xylene can contribute to neurological effects including headaches, dizziness, tiredness, tremors, coordination disorders, anxiety disorders, memory insufficiency, even if they are not listed as carcinogens $\mathbf{s}^{4,5}$.

Benzene is also considered to be a reason for acute myelogenous leukemia (AML) and its derivatives, but it is not yet clear whether benzene contributes to lymphocytic hematologic neoplasms such as non-hodgkin lymphoma, acute and chronic lymphatic leukemia, or multiple myeloma ${ }^{6}$. Observing gasoline station workers demonstrates that average exposure level for benzene is 3.9 times more than normal; for toluene it is 5.5 more than normal. Risks caused by chronic exposure to harmful volatile organic solvents, and mixed vital cancer risks caused by benzene, ethylbenzene, formaldehyde and acetaldehyde indicate include cancer as well as other chronic health effects for exposed workers?.

Volatile organic solvents belong to a heterogeneous group of chemicals characterized by high vapour pressure. Volatile organic compounds have come under significant scrutiny of late in gasoline stations that emit these compounds. Environmental studies that assess related air quality have also become important ${ }^{8}$. It is thought that some petrol-derivative compounds are formed from a mixture of complex chemicals well-known to be genotoxic agents. It is reported by the IARC that exposure to some well-known compounds like benzene and its vapours have a carcinogenic effect ${ }^{9}$. Petrol derivatives are chemical mixtures that also contain well-known genotoxicants like benzene, and chronic occupational exposure to these derivatives create a genotoxic risk ${ }^{10}$.

According to a recent study, the urine of gasoline-exposed workers contains a high percentage of phenol ${ }^{11}$, which can also transform into potential toxic metabolites such as catechol and hydroquinone. They can oxidize to benzoquinones by myeloperoxidase enzyme (MPO) in bone marrow. Benzoquinones, quinones and other benzene metabolites can create a reactive oxygen species that can damage important macromolecular targets including DNA, proteins and lipids. Reactive products can bind to cellular molecules, proteins and DNA covalently, creating an alternative path, that potentially induces breakages of DNA bonds, sister chromatid exchange (SCE), micronucleus (MN) and chromosomal aberra- 
tions (CA). Single breakages of DNA bonds, SCE, MN and CA are reported in the leukocytes of workers who are occupationally exposed to benzene. It is suggested that benzene also plays a role in mutagenesis because of an indirect mechanism that causes oxidative DNA damage by inducing the formation of hydroxyl radicals from hydrogen peroxidase ${ }^{3}$.

The use of appropriate biomarkers in evaluating exposure or genotoxicity-dependent disorders is important in order to interpret the relevant data correctly ${ }^{12}$. The Comet (single cell gel electrophoresis, SCGE) technique is a rapid, sensitive and cheap method that is used for assessing DNA damage ${ }^{13}$. Due to its high sensitivity, this assay is more advantageous than other methods of determining DNA-damage ${ }^{14}$. With this technique, the degree of damage can also be visually observed by evaluating nuclei as tailless, short tail (where the occurrence of stretches in DNA strands is more likely than individual fraction migration at low damage levels) and long tail (with an increase in breakage numbers, DNA fractions migrate freely from the nucleus, creating a 'comet' like appearance) $)^{15}$.

The objective of this study was to evaluate the level of DNA damage in fuel filling station workers using the alkaline Comet technique, and for this purpose peripheral blood samples were collected from exposed workers and the control group.

\section{METHODOLOGY}

\section{Study and Control Groups}

The research was performed on 25 workers between the ages of 20 and $57 \mathrm{emp}$ loyees at various busy gasoline stations in Istanbul as well as on 14 control subjects. A short survey containing questions about demographical characteristics and factors that enhance DNA damage is given to all participants. Ethical approval for this study was obtained from Marmara University's Institute of Health Sciences (30.03.2011 - 20).

\section{Analysis}

Blood sampling and lymphocyte preparation: Approximately $0.5 \mathrm{ml}$ of peripheral blood samples were collected from volunteers in sterile disposable syringes, and transferred into heparinized tubes. Unstimulated lymphocytes were isolated by Histopaque 1077 density gradient centrifugation, washed in phosphate-buffered saline (PBS), and resuspended in ice-cold PBS at $5 \mathrm{X1O}^{3}$ to $1 \mathrm{x} 1 \mathrm{O}^{4}$ cells/ml, respectively. Viability was tested by trypan blue exclusion. The number of dye-excluding cells always exceeded $90 \%$.

\section{Comet assay}

Chemicals: Unless otherwise stated, all chemicals were purchased from Sigma 
Chemical (Steinhelm, Germany). Superfrost 1.0-1.2 mm thick microscope slides were obtained from Menzel (Braunschweig, Germany).

Slide preparation: The alkaline comet assay was performed using an adaptation of the method of Singh et $a l^{16}$. Fully frosted microscope slides were dipped briefly into $\left(60^{\circ} \mathrm{C}\right), 0.7 \%$ normal melting agarose (NMA) prepared in PBS. The slides were dried overnight at room temperature and then stored at $4{ }^{\circ} \mathrm{C}$ until examined. Prepared cells (50.000) were mixed with $0.7 \%$ low melting point agarose (LMA) and placed on microscope slides. After adding the cell-containing layer, a second layer of LMA was added to fill in any residual holes in the second agarose layer, and to increase the distance between the cells and the gel surface. The slides were maintained on an ice-cold flat tray for 15 min to solidify. The slides were then carefully immersed in cold lysing solution (2.5 M NaCl, $100 \mathrm{mM}$ $\mathrm{Na}_{2}$ EDTA, $10 \mathrm{mM}$ Tris, $\mathrm{pH}$ 10) for at least $1 \mathrm{~h}$ at $4^{\circ} \mathrm{C}$.

Electrophoresis: The slides were removed from the lysing solution, drained and placed in a horizontal electrophoresis tank. The tank was filled with fresh electrophoresis buffer ( $0.3 \mathrm{M} \mathrm{NaOH}, 1 \mathrm{mM}$ EDTA, $\mathrm{pH}$ 13) to a level just covering the slides. Before electrophoresis, the slides were left in the solution for $20 \mathrm{mi}-$ nutes to allow for the unwinding of the DNA and the expression of alkali-labile damage. Subsequently, the DNA was electrophoresed for 30 minutes at $300 \mathrm{~mA}$ and $15 \mathrm{~V}$. To prevent additional DNA damage, all of the steps described above were conducted in the dark at $4^{\circ} \mathrm{C}$. After electrophoresis, the slides were taken from the tank and washed three times ( 5 min each) with $0.4 \mathrm{M}$ Tris buffer, $\mathrm{pH}$ $7 \cdot 5$ to neutralize the excess alkali. After the neutralization process, slides washed with varying concentrations of cold ethanol (50\%, 75\%, 100\%) respectively, in 5 minutes intervals. Then the slides were lined on paper to dry, and kept in a cold, dry environment before the dyeing process.

Staining: $50 \mathrm{ml}$ ethidium bromide ( $\mathrm{EtBr}-20 \mathrm{ml} / \mathrm{ml})$ was added to each slide. The slides were covered with a cover-slip, stored in a humidified box at $4^{\circ} \mathrm{C}$, and analyzed using a fluorescence microscope within 3-4 hours.

Scoring: The analysis of 100 randomly selected cells per subject was kept at 40× magnification, under a fluorescence microscope (Olympus, BX51). Cells were scored visually into five classes according to tail size, in order to facilitate the management of the data. The mean total comet scores (mean TCS) were calculated as follows: TCS $=0 \times$ no migration $+1 \times$ low migration $+2 \times$ medium migration $+3 \times$ high migration $+4 \times$ extensive migration, following Collins ${ }^{17}$.

\section{Statistical Analysis}

SPSS 17 statistical software (Statistical Package for Social Sciences Inc, Chicago, 
IL, USA) was used for the statistical analyses of the results. All results were expressed as means \pm Standart Deviation (SD); data are assigned a number or percentage where a p-value less than 0.05 was defined as statistically significant. A Shapiro Wilk test was conducted to determine whether the results of the analysis were in accordance with a normal distribution. The differences between the two independent groups at variance with a normal distribution were measured by the Mann-Whitney U test. The mean values among the three groups were compared using the Kruskal-Wallis test. The correlation between continuous variables was evaluated by spearman's correlation. Qualitative variables were expressed as a percentage of the respective groups and the differences were tested with the Chi square $\left(\chi^{2}\right)$ test.

\section{RESULTS AND DISCUSSION}

Gasoline is a colorless, pale brown or pink fluid. Increased use of gasoline products in automobiles and industry has had a negative impact on human health and air quality. Some products contain carcinogenic compounds ${ }^{4}$. Benzene is a natural component of crude oil that is mixed with toluene and xylene in petrol ${ }^{18,5}$.

Significant DNA damage can result from occupational exposure. The level of exposure depends on shift length, job rotation, individual precautions and workplace conditions ${ }^{19}$.

The results of the analysis were in accordance with the normal distribution as evaluated by the Shapiro Wilk test, and this difference was statistically significant $(\mathrm{p}=0.014)$. The correlation between continuous variables evaluated by Spearman's correlation, such as the effect of age on TCS; the effect of age was not significant on TCS in workers $(\mathrm{p}=0.263)$. The results of comparing the control group with the exposed group with respect to demographical characteristics (age, smoking habit) are given in Table 1. There was no significant difference between groups where demographic properties are such that $\mathrm{p}>0.05$.

The TCS frequency observed in workers $(89.24 \pm 30.83)$ was higher than the TCS of the control group (15.64 \pm 16.17$)$ (Table 2).

As for the duration of exposure, the groups were categorized as follows; less than 5 years, 5-20 years, and more than 20 years of exposure. The effect of occupational exposure on TCS was determined by a Kruskal-Wallis test and there were no significant differences $(\mathrm{p}=0.398)$. [Duration of exposure $<5$ years TCS $(92.60$ $\pm 26.77)$; 5-20 years TCS (82.29 \pm 41.63$)$; > 20 years TCS $(88.67 \pm 30.55)]$. Comparisons between the TCS frequency according to duration of occupational exposure are shown in Figure 1. Although none of the smokers in either the exposed or control groups were heavy smokers (the number of cigarettes currently 
smoked per day was 1-8 cigarettes) and although the sample size is small, DNA damage was more apparent in exposed smokers. Taken together, meta-analysis on the basis of 38 studies (from 37 publications), with 803 smokers and 959 nonsmokers confirms that smoking has a DNA damaging effect on peripheral blood cells as measured by the comet assay ${ }^{20}$. Seven of our previously published papers appear in the above meta-analysis; they contain results similar to those observed in this study, indicating that DNA damage levels were higher in occupationally exposured smokers.

Basal DNA damage is considered to be influenced by extended periods of work in polluted environments. Although the exposed subjects who worked less than five years or between 5-20 years had elevated DNA damage, no significant increase in DNA damage was observed in workers exposed for more than twenty years. However, Sardas et al. (2010) supports our observation by indicating the relation between the DNA damage and DNA repair ${ }^{19}$.

The photograph in Figure 2 shows comet cells from a healthy control, and Figure 3 shows comet cells from a gasoline station worker. Changes in the values of the blood parameters of workers chronically exposed to benzene were reported by Qu et al. in 2002 ${ }^{21}$. Similar observations by Ray et al. in 2007 indicated decreased erythrocyte, hemoglobin, lymphocyte and thrombocyte levels, whereas neutrophil, band cell, and target cell levels were increased in gasoline workers who use materials with benzene and in workers employees at car service stations ${ }^{22}$. On the other hand, studies of gasoline workers exposed to petrol products reveal multiple myeloma risks ${ }^{23}$, exocrine pancreatic cancer development ${ }^{24}$, increased prostate cancer incidence ${ }^{25}$ at levels significantly higher than those of control groups. Reviews by Smith, M.T., et al and Vlaanderen. J. et al summarize the case-control and cohort evidence studies that evince an association between cancer incidence and occupational benzene exposure ${ }^{26,27}$.

Analysis of buccal cells revealed that micronucleus frequencies in gasoline station workers were significantly higher than in control subjects; as well the average urine phenol levels of station workers were significantly higher than those in the control group ${ }^{28}$. In a study employing the Comet technique on age-matched workers, Andreoli et al showed that significant DNA damage in lymphocytes resulting from exposure to low benzene levels was higher than that of the control group ${ }^{29}$. A similar observation was reported in a 2008 study of Indian gasoline workers where workers were subject to higher exposure conditions to p-benzocaine, a metabolite of gasoline, than the control group ${ }^{11}$. In a similar study, workers from gas stations and a refinery plant who were occupationally exposed to benzene were evaluated by blood benzene concentrations; median occupational benzene exposure was lower in the morning after a shift than at end of shift ${ }^{30}$. 
In conclusion, total comet scores in randomly selected workers in gasoline stations were significantly higher than in control subjects. Since benzene is a relatively common environmental and occupational contaminant, the genotoxic effect on human health status remains a matter of concern, and the biomarkers of such effects are valuable predictors in assessing potential risks. This preliminary study needs to continue by monitoring more detailed risk assessment parameters such as ambient air, exposure levels, blood and urine concentration measurements, and clinical neurological effects such as findings related to headaches, sleeping disorders, memory loss, general tiredness, with long term follow-up in order to provide important public health information regarding fuel exposure.

\section{Author Contributions}

These authors contributed equally.

Table 1: The comparison of control and gasoline station workers with respect to demographical characteristics (age, smoking).

\begin{tabular}{cccc}
\hline \hline & $\begin{array}{c}\text { Control } \\
(\mathbf{n}=\mathbf{1 4})\end{array}$ & $\begin{array}{c}\text { Gasoline station workers } \\
(\mathbf{n}=\mathbf{2 5})\end{array}$ & $\mathbf{p}$ \\
\hline \hline $\begin{array}{c}\text { Age; } \text { mean } \pm \text { SD } \\
\text { (median) }\end{array}$ & $\begin{array}{c}39.90 \pm 13.30 \\
(40)\end{array}$ & $\begin{array}{c}32.12 \pm 11.29 \\
(28)\end{array}$ & ${ }^{a} \mathbf{p}=\mathbf{0 . 0 9 2}$ \\
\hline Non Smoker & $9(64.29 \%)$ & $12(48 \%)$ & \\
\hline Smoker & $5(35.71 \%)$ & $13(52 \%)$ & \\
\hline \hline
\end{tabular}

$\boldsymbol{n}$ : number $\boldsymbol{n}$ (\%): percentage of group $\quad{ }^{\mathrm{a}}$ : Mann-Whitney $U$ test $\quad{ }^{\dagger}$ : Chi square test

Table 2: Comparisons between the Total comet score in gasoline station workers and unexposed controls expressed as Mean \pm SD.

\begin{tabular}{|c|c|c|c|c|c|c|c|}
\hline & & \multirow{2}{*}{$\mathrm{n}$} & \multicolumn{4}{|c|}{ TCS } & \multirow{2}{*}{$\mathbf{p}^{\mathbf{a}}$} \\
\hline & & & Mean & \pm & SD & median & \\
\hline \multirow{2}{*}{\multicolumn{2}{|c|}{$\begin{array}{l}\text { Control } \\
\text { Gasoline station workers }\end{array}$}} & 14 & 15.64 & \pm & 16.17 & 12 & \multirow{2}{*}{0.001} \\
\hline & & 25 & 89.24 & \pm & 30.83 & 83 & \\
\hline \multirow{2}{*}{ Control } & Smoker & 5 & 13.6 & \pm & 8.44 & 13 & \multirow{2}{*}{0.738} \\
\hline & Nonsmoker & 9 & 16.77 & \pm & 19.62 & 11 & \\
\hline \multirow{2}{*}{ Gasoline station workers } & Smoker & 13 & 92.92 & \pm & 36.54 & 77 & \multirow{2}{*}{0.978} \\
\hline & Nonsmoker & 12 & 85.25 & \pm & 24.15 & 84.5 & \\
\hline \multirow{3}{*}{ Nonsmoker } & Control & 9 & 16.77 & \pm & 19.62 & 11 & \multirow{3}{*}{0.001} \\
\hline & Gasoline & & & & & & \\
\hline & $\begin{array}{l}\text { Station } \\
\text { workers }\end{array}$ & 13 & 85.25 & \pm & 24.15 & 84.5 & \\
\hline
\end{tabular}

n: number

SD: standard deviation

a: Mann-Whitney Utest 
TCS: Total Comet Score

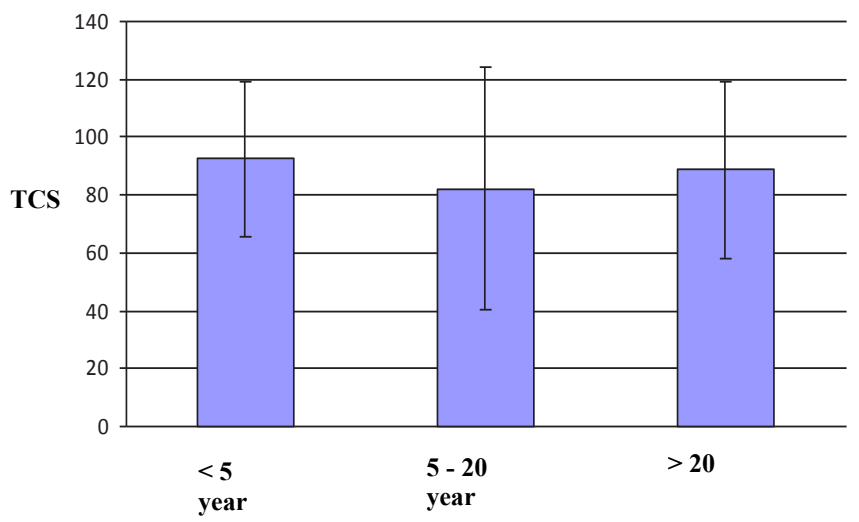

Figure 1: The comparison of Total Comet Scores with respect to duration of occupational exposure

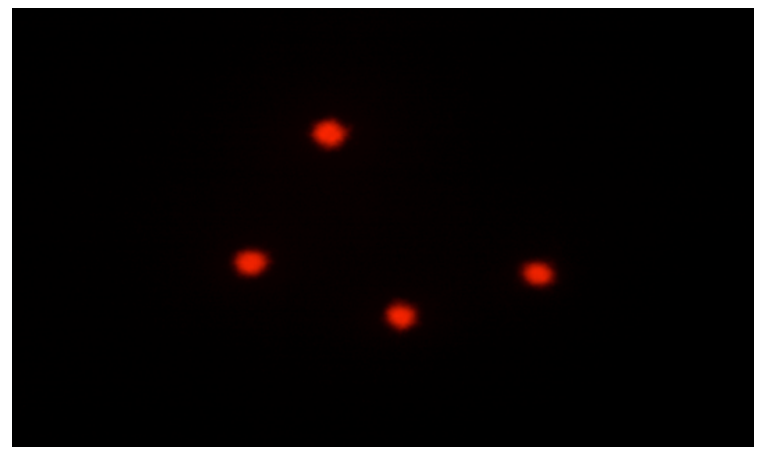

Figure 2: Comet cells from a healthy control.

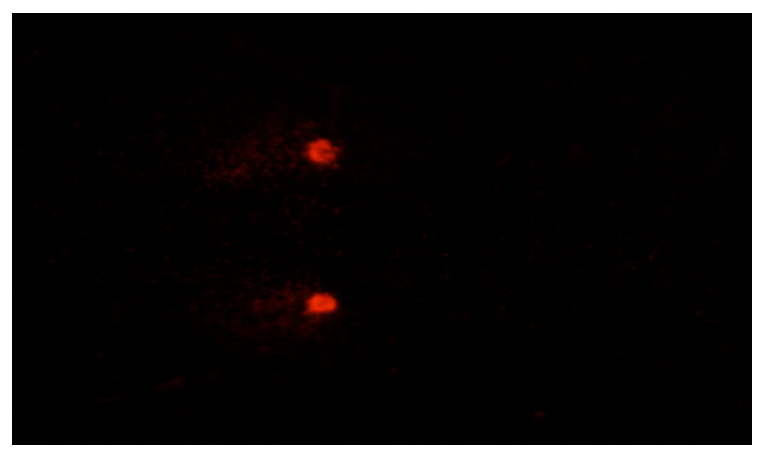

Figure 3: Comet cells from a gasoline station worker. 


\section{REFERENCES}

1. Whysner, J.; Reddy, M. V.; Ross, P. M.; Mohan, M.; Lax, E. A. Genotoxicity Of Benzene And Its Metabolites. Mutat. Res. 2004, 566, 99-130.

2. Bindhya, S.; Balachandar, V.; Sudha, S.; Devi, S. M.; Varsha, P.; Kandasamy, K.; Prakash, V. G.; Sasikala, K. Assessment Of Occupational Cytogenetic Risk, Among Petrol Station Workers. Bull. Environ. Contam. Toxicol. 2010, 85, 121-124.

3. Fracasso, M. E.; Doria, D; Bartolucci, G. B.; Carrieri, M.; Lovreglio, P.; Ballini, A.; Soleo, L.; Tranfo, G.; Manno, M. Low Air Levels Of Benzene:Correlation Between Biomarkers Of Exposure And Genotoxic Effects. Toxicol. Lett. 2010, 192, 22-28.

4. Rekhadevi, P. V.; Rahman, M. F.; Mahboob, M.; Grover, P. Genotoxicity In Filling Station Attendants Exposed To Petroleum Hydrocarbons. Ann. Occup. Hyg. 2010, 54, 944-954.

5. Rekhadevi, P. V.; Mahboob, M.; Rahman, M. F.; Grover, P. Determination Of Genetic Damage And Urinary Metabolites In Fuel Filling Station Attendants. Environ. Mol. Mutagen. 2o11, 52, 310-318.

6. Sul, D.; Lee, E.; Lee, M. Y.; Oh, E.; Im, H.; Lee, J.; Jung, W. W.; Won, N.; Kang, H. S.; Kim, E. M.; Kang, S. K. DNA Damage In Lymphocytes Of Benzene Exposed Workers Correlates With Trans, Trans-Muconic Acids And Breath Benzene Levels. Mutat. Res. 2005, 582, 61-70.

7. Majumdar, D.; Dutta, C.; Mukherjee, A. K.; Sen, S. Source Apportionment of VOCs At The Petrol Pumps In Kolkata, India; Exposure Of Workers And Assessment Of Associated Health Risk. Transp. Res. Part. D. 2008, 13, 524-530.

8. Morales Terres, I. M.; Minarro, M. D.; Ferradas, E. G.; Caracena, A. B.; Rico, J. B. Assessing The Impact Of Petrol Stations On Their Immediate Surroundings. J. Environ. Manage. 2010, 91, 2754-2762.

9. Martins, R. A., Silva Gomes, G. A.; Jr Aguiar, O.; Ribeiro, D. A. Biomonitoring Of Oral Epithelial Cells In Petrol Station Attendants: Comparison Between Buccal Mucosa And Lateral Border Of The Tongue. Environ. Int. 2009, 35, 1062-1065.

10. Elisabeth Caplun, B. A.; Daniel Petit, P. D.; Edgard Picciotto, P. D. Lead in petrol. Endeavour, 1984, 8, 135-144.

11. Pandey, A. K.; Bajpayee, N.; Parmar, D.; Kumar, R.; Rastogi, S. K.; Mathur, N.; Thorning, P.; Matas, M.; Shao, Q.; Anderson, D.; Dhawan, A. Multipronged Evaluation Of Genotoxicity In Indian Petrol-Pump Workers. Environ. Mol. Mutagen. 2008, 49, 695-707.

12. Neri, M.; Bonassi, S.; Knudsen, L. E.; Sram, R. J.; Hollan, N.; Ugolini, D.; Merlo, D. F. Children's Exposure To Environmental Pollutants And Biomarkers Of Genetic Damage. I. Overview And Critical Issues. Mutat. Res. 2006, 612, 1-13.

13. Fairbain, D. W.; Olive, P. L.; O’Neill, K. L. The Comet Assay: A Comprehensive Review, Mutat. Res. 1995, 339, 37-59.

14. Richard, F. L.; Steinert, S. Use Of The Single Cell Gel Electrophoresis/Comet Assay For Detecting DNA Damage In Aquatic (Marine And Freshwater) Animals. Mutat. Res. 2oo3, 544, 43-64.

15. Karabıyık, L.; Sardas, S.; Polat, U.; Kocabaş., N. A.; Karakaya, A. E. Comparison Of Genotoxicity Of Sevoflurane And Isoflurane In Human Lymphocytes Studied In Vivo Using The Comet Assay. Mutat. Res. 2001, 492, 99-107.

16. Singh, N. P.; McCoy, M.; Tice, R. R.; Schneid, E. L. A Simple Technique For Quantitation Of Low Levels Of DNA Damage In Individual Cells. Exp. Cell. Res. 1988, 175, 184-191. 
17. Collins, A. R. The Comet Assay. Principles, Applications, And Limitations. Methods. Mol. Biol. 2002, 203, 163-177.

18. Paz-y-Mino, C.; Lopez-Cortes, A.; Arevalo, M.; Sanchez, M. E. (2008). Monitoring of DNA Damage In Individuals Exposed To Petroleum Hydrocarbons In Ecuador. Ann. N.Y. Acad. Sci. 2008, 1140, 121-128.

19. Sardas, S.; Omurtag, G. Z.; Tozan, A.; Gül, H.; Beyoglu, D. Evaluation Of DNA Damage In Construction-Site Workers Occupationally Exposed To Welding Fumes And Solvent Based Paints In Turkey. Toxicol. Ind. Health. 2010, 26, 601-608.

20. Hoffmann, H; Ho"gel, J; Speit G. The Effect Of Smoking On DNA Effects In The Comet Assay: A Meta-Analysis. Mutagenesis. 2005, 20, 455-466.

21. Qu, Q; Shore, R. L. G.; Jin, X.; Chen, L. C.; Cohen, B.; Melikian, A. A.; Eastmond, D.; Rappaport, S. M.; Yin, S.; Li, Y.; Mu, R.; Zhang, X.; Li, K. Hematological Changes Among Chinese Workers With A Broad Range Of Benzene Exposures. Am. J. Ind. Med. 2002, 42, 275-285.

22. Ray, M. R.; Roychoudhury, S.; Mukherjee, S.; Lahiri, T. Occupational Benzene Exposure From Vehicular Sources In India And Its Effect On Hematology, Lymphocyte Subsets And Platelet P Selectin Expression. Toxicol. Ind. Health. 2007, 23, 167-175.

23. Kirkeleit, J.; Riise, T.; Bratveit, M.; Moen, B. E. Increased Risk Of Acute Myelogenous Leukemia And Multiple Myeloma In Ahistorical Cohort Of Upstream Petroleum Workers Exposed To Crude Oil. Cancer Causes Control. 2008, 19, 13-23.

24. Alguacil, J.; Porta, M.; Malats, N.; Kauppinen, T.; Kogevinas, M.; Benavides, F.G.; Partanen, T.; Carrato, A. Occupational Exposure to Organic sSvents and K-ras Mutations in Exocrine Pancreatic Cancer. Carcinog. 2002, 23, 101-106.

25. Krishnadasan, A; Kennedy, N; Zhao, Y; Morgenstern, H; Ritz, B. Nested Case-Control Study Of Occupational Chemical Exposures And Prostate Cancer In Aerospace And Radiation Workers. Am. J. Ind. Med. 2007, 50, 383-390.

26. Smith, M.T.; Jones, R.M.; Smith, A.H. Benzene Exposure and Risk of Non-Hodgkin Lymphoma. Cancer. Epidemiol. Biomarkers. Prev. 2007, 16, 385-391.

27. Vlaanderen, J.; Lan, Q.; Kromhout, H.; Rothman, N.; Vermeulen, R. Occupational Benzene Exposure and the Risk of Lymphoma Subtypes: A Meta-Analysis of Cohort Studies Incorporating Three Study Quality Dimensions. Environ. Health. Perspect. 2011, 119, 159-167.

28. Çelik, A.; Çavaş, T.; Gözükara Ergene, S. Cytogenetic Biomonitoring In Petrol Station Attendants: Micronucleus Test In Exfoliated Buccal Cells. Mutagenesis. 2003, 18, 417-421.

29. Andreoli, C.; Leopardi, P.; Crebelli, R. Detection of DNA Damage in Human Lymphocytes By Alkaline Single Cell Gel Electrophoresis After Exposure To Benzene Or Benzene Metabolites. Mutat. Res. 1997, 377, 95-104.

30. Brugnone, F.; Perbellini, L.; Romeo, L.; Cerpelloni, M.; Bianchin, M.; Tonello, A. Benzene in Blood as a Biomarkers Of Low Level Occupational Exposure. Sci. Total. Environ. 1999, 235, 247-252. 